\title{
Situation of Water, Hygiene and Sanitation in a Peri-Urban Area in Benin, West Africa: The Case of Sèmè-Podji
}

\author{
Roch Christian Johnson', Hadehou Segla', Tamègnon Victorien Dougnon ${ }^{1,2 *}$, \\ Gratien Boni1, Honoré Sourou Bankole ${ }^{2}$, Christophe Houssou' ${ }^{1}$, Michel Boko' ${ }^{1}$ \\ ${ }^{1}$ Laboratory of Hygiene, Sanitation ,Toxicology and Environmental Health, Interfaculty Center of Training and \\ Research in Environment for the Sustainable Development, University of Abomey-Calavi (UAC), Cotonou, Benin \\ ${ }^{2}$ Research Laboratory in Applied Biology, Polytechnic School of Abomey-Calavi, University of Abomey-Calavi, \\ Cotonou, Benin \\ Email: ${ }^{*}$ victorien88@hotmail.com, dougnonv@yahoo.fr
}

Received 23 July 2014; revised 21 August 2014; accepted 16 September 2014

Copyright @ 2014 by authors and Scientific Research Publishing Inc.

This work is licensed under the Creative Commons Attribution International License (CC BY).

http://creativecommons.org/licenses/by/4.0/

(c) (i) Open Access

\section{Abstract}

This study aimed to analyze the environmental factors related to health vulnerability in the municipality of Sèmè-Podji. For this study, 216 households were surveyed using questionnaires. Twelve key informants were enrolled for depth interviews and 18 water samples were collected from different sources used by the populations. It came out of our investigations that water from traditional sources used at Sèmè-Podji was contaminated by various microorganisms such as Escherichia coli and fecal coliforms. $66.38 \%$ of households reject domestic waste and $47.41 \%$ of them evacuate sewage in the yard. In addition, $93.05 \%$ drop stagnant water for natural infiltration. This municipality faces lack of sanitation. The main health problems experienced by people were malaria $(46.35 \%)$, diarrheal diseases $(15.88 \%)$. The study stated some results which could improve the help about health management in the area.

\section{Keywords}

Sèmè-Podji, Environment, Health, Vulnerability, Population

\section{Introduction}

Several studies have emphasized on the sanitary risks associated with poor environmental conditions [1]-[4].

${ }^{*}$ Corresponding author.

How to cite this paper: Johnson, R.C., Segla, H., Dougnon, T.V., Boni, G., Bankole, H.S., Houssou, C. and Boko, M. (2014) Situation of Water, Hygiene and Sanitation in a Peri-Urban Area in Benin, West Africa: The Case of Sèmè-Podji. Journal of Environmental Protection, 5, 1277-1283. http://dx.doi.org/10.4236/jep.2014.512121 
Commonly, the interactions between urbanization, environment and health in developing countries were not taken in account in the process of territory occupation [5]. Sèmè-Podji is a sub-urban municipality located between the two major cities in Benin (West Africa): Cotonou which is the economic capital and Porto-Novo which is the political one [6]. This municipality is composed by an important number of underprivileged villages and neighbourhoods in which the populations live mostly in precarious and low quality dwellings. Because of the high demographic pressure due to various factors such as job hunting, influx of rural populations, installation of second-hand vehicles selling parks, Sèmè-Podji became the second dormitory town of Cotonou, the biggest city of Benin after Abomey-Calavi [6]. Consequently, it faces a fast and uncontrolled urbanization that results in a multiple environmental issues such as difficulties to access potable drinking water and sanitation, management of wastewater, collection of garbage, and evacuation of rainwater. These deficiencies observed in the area of water, hygiene and sanitation confer to this commune, an unhealthy environment and expose the population to various health risks [7]. This study was done to analyse the environmental factors associated with the poor water, hygiene and sanitation in this suburban community and its consequences on the health of the population.

\section{Materials and Methods}

Sub districts of Tohouè, Ekpè and Sèmè-Podji constitute the locations of this study whereby different types of data were collected. Data related to the microbiological and physicochemical parameters of water used by the population, data gotten from the household heads survey conducted through questionnaires and finally data from in depth interview of keys informants.

\subsection{Sample Collection and Analysis of the Drinking Water}

The bacteriological and physico-chemical analyses were achieved on water samples in the laboratory of the National Directory of Public Health in Cotonou. A total of 18 water samples were collected in order to appreciate the health risks associated to the consumption of such water. Water samples were collected at the sources mostly used by the population and in the households using sterile glass bottles of $500 \mathrm{ml}$. These bottles were washed, rinsed with distilled water and sterilized. In the case of samples collection from boreholes and taps of the urban water supply system, water was let in continuous diffusion during 3 to 5 minutes before samples were collected. Water samples were then collected in glass bottles, having a plug in polystyrene that is opened only at the time of the collection. In the households, samples were collected directly from the storage containers. Once sample is collected, the bottles were automatically labelled and placed in ice boxes at $4{ }^{\circ} \mathrm{C}$ up to the laboratory. Wells water samples have also been collected for assessment.

Standardized methods adopted by the member's states of the Economic and Monetary Union of West Africa (UEMOA) were used in the implementation of this study [5].

\subsection{Investigation by Questionnaire}

216 households' heads were randomly selected for the questionnaire survey. In addition, 12 keys informants were enrolled for in depth interview. The questionnaires and checklists were first prepared in French and then translated to Goun (native language of study participants). Data quality was checked every day by the principal investigator for its completeness and errors in the questionnaire. Training for data collectors and pre-test were conducted. For the in depth interview, participants were selected and related issues were discussed. The level of saturation of information was used to decide the number of interviews. The principal investigator moderated all the in-depth interviews. In addition to hand written notes during the interview, interviews were tape-recorded. They were later transcribed and translated to French. Privacy and confidentiality of the clients as well as good interaction between individuals and interviewers were maintained during the data collection and interview time. An observation checklist enabled the research team to record additional information directly on the field. It also permitted to describe the hygiene and sanitation habits and practices in use in the municipality.

\subsection{Data Treatment and Analysis of the Results of the Interviews}

Data were checked, coded, and entered with the help of Statistical Package for the Social Sciences (SPSS) version 21.0. The transcripts of the qualitative data were coded using a coding scheme and analysis was done according to selected themes. 
First of all, an inventory of the various sanitation devices and the sources of drinking water supply as well as their use were completed. According to the typology of the water supplying facilities; the Cover Rate (CR) of the study area was calculated. Then, health related problems as well as the frequency and the distribution of some diseases were investigated.

\section{Results and Discussion}

\subsection{Water Supplying Sources}

The water supplying sources used by the studied population were rainwater, traditional or modern wells, boreholes and the water from the national water company. These sources are often used alone or in combination. In our study, water from the national water company and boreholes are considered as improved water. The coverage of improved water sources in the study area is presented by the Figure 1. This figure shows a wide disparity in the coverage of drinking water in the study area. The coverage of the village of Tohouè is the highest (475.23\%). This means that there was much more water points installed than needed. By the contrast, Glogbo, Ekpè II Seme-Podji, Kpogui Wégbédo are villages that show respective rates of $0 \%, 1.3 \%, 3.9 \%$, $6.38 \%$ and $8.34 \%$. Overall, in the study area, the coverage rate of improved water sources is about $20.03 \%$ which is significantly lower than the value (69.8\%) required to achieve the MDGs on the departmental plan. Similar findings of an unequal distribution of improved water infrastructures were also reported by several authors [8] [9].

In-depth interviews reveal that in case of insufficient coverage, the population uses traditional wells to satisfy their water needs. However, the results, as others studies [9]-[11] show that these traditional water sources are polluted because of human behaviors and mismanagement.

\subsection{Microbiological and Physicochemical Quality of Water}

Table 1 shows that tap waters presented good microbiological and physicochemical quality. It appears that the bacteriological quality of water from boreholes and national water society was acceptable at the distribution point. By the contrast, all samples from traditional wells were contaminated with faecal coliforms and $E$. coli that exceed the standard recommended by the WHO [1]. At the household level, the microbiological quality of the water used was also insufficient reflecting pollution during transport and storage. In-depth interviews revealed, as others studies [12]-[15] that rightly transport and storage of water are made in conditions that favor contamination by microorganisms (leaves in the containers for transportation, conservation of water for several days in the same vessel, immersing of hands in the storage container).

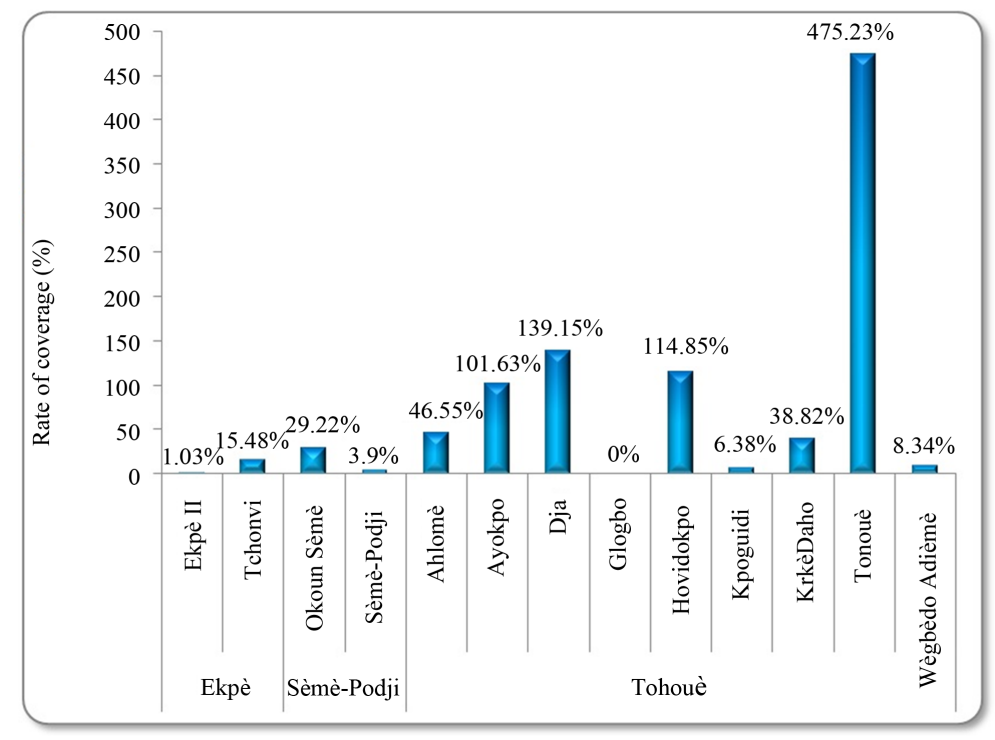

Figure 1. Coverage rate of improved drinking water of the study area according to data from ministry of water resources. 
Table 1. Bacterial load and physicochemical quality of the drink waters.

\begin{tabular}{|c|c|c|c|c|c|c|c|c|c|c|}
\hline Districts & Locations & $\begin{array}{c}\text { Parameters } \\
\text { samples }\end{array}$ & $\begin{array}{c}\text { Controlled } \\
\text { level }\end{array}$ & $\begin{array}{c}\text { Faecal } \\
\text { coliforms/ } \\
100 \mathrm{ml}\end{array}$ & $\begin{array}{c}\text { Escherichia } \\
\text { coli/100ml }\end{array}$ & pH & TDS & $\begin{array}{l}\text { Cond. } \\
(\mu \mathrm{S} / \mathrm{cm})\end{array}$ & $\mathrm{T}\left({ }^{\circ} \mathrm{C}\right)$ & $\begin{array}{l}\text { Chlorine } \\
\text { residue }\end{array}$ \\
\hline & & $\begin{array}{c}\text { WHO } \\
\text { standards }\end{array}$ & S & 0 & 0 & [6.5 8.5] & - & 1400 & $25^{\circ}$ & 0.5 \\
\hline \multirow{10}{*}{ Tohouè } & \multirow{10}{*}{ Ayokpo } & \multirow{2}{*}{01 Boring } & S & 00 & 00 & 6.82 & 41.1 & 82.4 & $29^{\circ} 8$ & \\
\hline & & & $\mathrm{H}$ & 91 & 68 & - & - & - & - & \\
\hline & & \multirow{2}{*}{$\begin{array}{l}02 \text { traditional } \\
\text { wells }\end{array}$} & S & 67 & 07 & 6.82 & $8 ., 5$ & 166.9 & $28^{\circ} 2$ & \\
\hline & & & $\mathrm{H}$ & 1840 & 00 & 6.82 & 112 & 223 & $27^{\circ} 7$ & \\
\hline & & \multirow{2}{*}{$\begin{array}{l}03 \text { Boring/water } \\
\text { in plastic bag }\end{array}$} & S & 00 & 00 & 6.90 & 114 & 229 & $29^{\circ} 4$ & \\
\hline & & & $\mathrm{H}$ & 00 & 00 & - & - & - & - & \\
\hline & & \multirow{2}{*}{04 SONEB } & S & 00 & 00 & 6.80 & 64.4 & 128.6 & $29^{\circ} 0$ & 0.3 \\
\hline & & & $\mathrm{H}$ & 00 & 00 & 6.80 & 62.8 & 125.6 & $28^{\circ} 6$ & \\
\hline & & \multirow{2}{*}{05 Wells } & S & 37 & 17 & 6.78 & 104.0 & 210.0 & $29^{\circ} 3$ & \\
\hline & & & $\mathrm{H}$ & 61 & 48 & 6.80 & 101.0 & 204.0 & $28^{\circ} 5$ & \\
\hline \multirow{4}{*}{ Sèmè-Podji } & \multirow{4}{*}{ Sèmè } & \multirow{2}{*}{06 SONEB } & S & 00 & 00 & 6.81 & 33.7 & 67.3 & $28^{\circ} 1$ & 0.45 \\
\hline & & & $\mathrm{H}$ & ND & - & - & - & - & - & \\
\hline & & \multirow{2}{*}{07 SONEB } & S & 00 & 00 & 6.80 & 34.00 & 67.8 & $30^{\circ} 1$ & 0.45 \\
\hline & & & $\mathrm{H}$ & 400 & 00 & 6.80 & 24.9 & 49.9 & $25^{\circ} 0$ & \\
\hline \multirow{4}{*}{ Ekpè } & \multirow{4}{*}{ Ekpè I } & \multirow{2}{*}{08 SONEB } & S & 00 & 00 & 6.80 & 38.5 & 77.0 & $28^{\circ} 8$ & \\
\hline & & & $\mathrm{H}$ & 232 & 198 & 6.80 & 31.3 & 62.7 & $28^{\circ} 1$ & \\
\hline & & \multirow{2}{*}{$\begin{array}{l}09 \text { traditional } \\
\text { wells }\end{array}$} & S & 285 & 95 & 6.80 & 90.10 & 181.3 & $30^{\circ} 6$ & \\
\hline & & & $\mathrm{H}$ & 3880 & 00 & 6.80 & 79.50 & 160.2 & $28^{\circ} 4$ & \\
\hline
\end{tabular}

S: Source. H = Households; ND: Non determined.

\subsection{Wastewaters Management}

In this area, very few households have satisfactory practices concerning the discharge of wastewaters since about 93.05\% households discharge wastewater directly in the nature (Table 2). It also shows that the study sector doesn't have any gutters for the evacuation of rainwaters. Consequently, households (93.05\%) abandon the stagnant waters for natural infiltration. In some households, precarious drainage systems discharge wastewater and rainwater in the streets. This situation exacerbates the numerous water pools present in the quasi-totality of the streets in the study area. Several studies showed that water pools that are gathered along the soil ways in Africa can constitute excellent larval lodgings for the vectors of malaria [16].

\subsection{Sanitation Practices}

Public latrines do not exist in Sèmè-Podji and Tohouè districts. Open defecation in nature is the common practices. 78.18\% of investigated households do not have any sanitation devices (Table 3). It is well known that human faeces are dangerous for health because of the pathogenic germs [3].

\subsection{Health Consequences of the Poor Hygiene and Sanitation}

The results showed malaria prevails in the three districts respectively with $33.87 \%$ for Ekpè, $48.98 \%$ for Sèmè-Podji and 47.86\% for Tohouè followed by diarrhoeal and gastroenteritis diseases (Table 4). 


\subsection{Trend of Malaria and Diarrhoeal Illnesses}

Figure 2 presents the inter-annual trends of the number of cases of the main diseases observed in the three districts of Sèmè-Podji Municipality from 2008 to 2012. The trends of malaria and diarrheal illness in the study area are relatively constants from 2008 to 2012 as shown on the figure. These trends are easily explained by the poor environnemental conditions described by the results of this study.

\section{Conclusion}

In the municipality of Sèmè-Podji, one of the major challenges is the issue of hygiene and sanitation. Access to drinking water and the different modes of water management, sanitation, poor management of garbage, disposal

Table 2. Modes of discharge of waste water.

\begin{tabular}{|ccc|}
\hline Modes of discharge of waste water & Frequency & Percentage (\%) \\
\hline Cesspool & 15 & 6.94 \\
Courtyard & 102 & 47.22 \\
Street & 99 & 45.83 \\
Gutters & 0 & 0 \\
Total & $\mathbf{2 1 6}$ & $\mathbf{1 0 0}$ \\
\hline
\end{tabular}

Table 3. Distribution of the defecation areas in the households having no latrines.

\begin{tabular}{cccccc}
\hline \multicolumn{2}{c}{ Sub-districts } & In the nature & In the neighbour' house & Public latrines & Total \\
\hline \multirow{2}{*}{ Ekpè } & Frequency & 12 & 2 & 10 & 24 \\
& $\%$ & 50 & 8.33 & 41.67 & 100 \\
Sèmè-Podji & Frequency & 12 & 2 & 0 & 14 \\
& $\%$ & 85,71 & 14.29 & 0 & 100 \\
Tohouè & Frequency & 62 & 10 & 0 & 10 \\
F & Frequency & 84,58 & 13.89 & 10 & 110 \\
\hline
\end{tabular}

Table 4. Distribution of the main reported diseases from the investigated households.

\begin{tabular}{|c|c|c|c|c|c|c|c|c|}
\hline \multirow{2}{*}{ Main diseases } & \multicolumn{2}{|c|}{ Ekpè } & \multicolumn{2}{|c|}{ Sèmè-Podji } & \multicolumn{2}{|c|}{ Tohouè } & \multicolumn{2}{|c|}{ Study sector } \\
\hline & Frequency & $\%$ & Frequency & $\%$ & Frequency & $\%$ & Frequency & $\%$ \\
\hline Malaria & 21 & 33.87 & 72 & 48.98 & 123 & 47.86 & 216 & 46.35 \\
\hline Gastroenteritis & 7 & 11.29 & 20 & 13.61 & 13 & 5.06 & 40 & 8.58 \\
\hline Diarrhoea & 19 & 30.65 & 34 & 23.13 & 21 & 8.17 & 74 & 15.88 \\
\hline Skin diseases & 8 & 12.9 & 4 & 2.72 & 9 & 3.5 & 21 & 4.51 \\
\hline Cholera & 0 & 0 & 4 & 2.72 & 11 & 4.28 & 15 & 3.22 \\
\hline Others & 7 & 11.29 & 13 & 8.84 & 80 & 31.13 & 100 & 21.46 \\
\hline Total & 62 & 100 & 147 & 100 & 257 & 100 & 466 & 100 \\
\hline
\end{tabular}



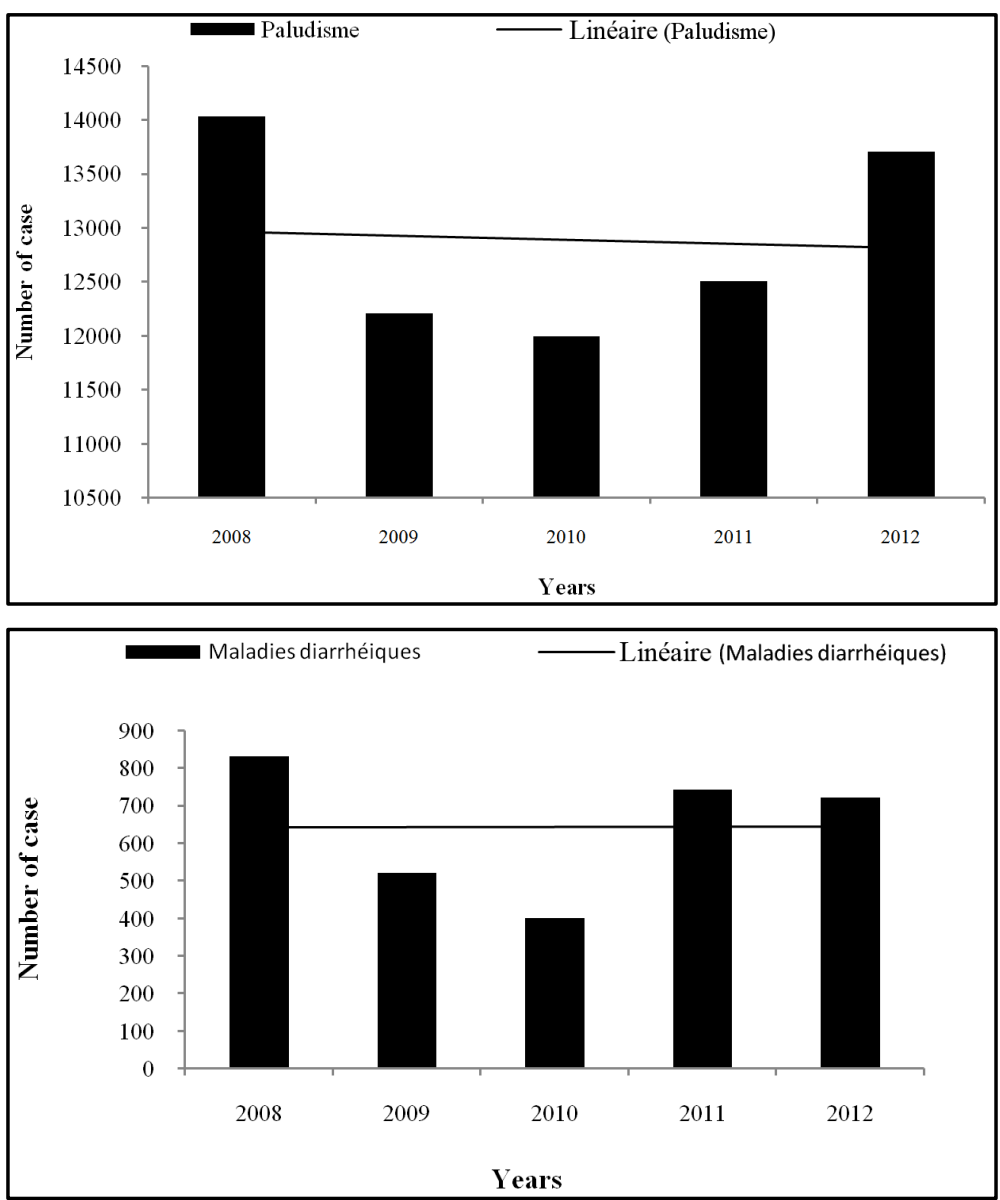

Figure 2. Inter-annual variation of the main diseases in the sector of study from 2008 to 2012 Source: DDS Ouémé-Plateau (2013).

of wastewater and excreta are major challenges identified by this study. These factors lead to various diseases that undermine the health of populations and inhibit the socio-economic development of the municipality. The most recurrent diseases are malaria and diarrheal diseases. Urgent actions need to be initiated to improve the living conditions of people in the Municipality of Sèmè-Podji.

\section{References}

[1] WHO and UNICEF (2013) Progress on Sanitation and Drinking-Water-2013 Update. Geneva, 40 p.

[2] Bartram, J. and Cairncross, S. (2010) Hygiene, Sanitation and Water, Forgotten Foundations of Health. PLoS Medicine, 7, 1-9. http://dx.doi.org/10.1371/journal.pmed.1000367

[3] Feachem, R., Bradley, D., Garelick, H. and Mara, D. (1983) Sanitation and Disease. Health Aspects of Waste Water and Excreta Management. John Wiley \& Sons, Chichester, 326 p.

[4] Hunter, P., MacDonald, A. and Carter, R. (2010) Water Supply and Health. PLoS Medicine, 7, e1000361. http://dx.doi.org/10.1371/journal.pmed.1000361

[5] DHAB (2010) Appui à la maîtrise d'ouvrage communale Guide d'élaboration et de mise en œuvre du Plan d'Hygiène et d'Assainissement Communal. Fiches techniques, Ministère de la Santé, DHAB, 77 p.

[6] INSAE (2012) Demographic and Health Survey (EDSB-III). Cotonou, 40 p.

[7] Afrique Conseil (2006) Monographie de la commune de Sème-Kpodji. Cotonou, 68 p.

[8] Johnson, R.C., Degbey, C. and Boni, G. (2012) Water, Hygiene and Sanitation in the Municipality of Zè. Climat et Développement, 11, 68-78.

[9] Degbey, C., Makoutode, M., Agueh, V., Dramaix, M. and de Brouwer, C. (2011) Factors Associated with the Quality 
of Well Water and Prevalence of Waterborne Diseases in the Town of Abomey (Benin). Cahier Santé, 21, 47-55.

[10] Mara, D., Lane, J., Scott, B. and Trouba, D. (2010) Sanitation and Health. PLoS Medicine, 7, e1000363. http://dx.doi.org/10.1371/journal.pmed.1000363

[11] Schmidt, P., Aunger, R., Coombes, Y., Maina, P., Matiko, C.N., Biran, A. and Curtis, V. (2009) Determinants of Hand Washing Practices in Kenya: The Role of Media Exposure, Poverty and Infrastructure. Tropical Medicine \& International Health, 14, 1534-1541. http://dx.doi.org/10.1111/j.1365-3156.2009.02404.x

[12] Dikassa, L., Mock, N., Magnani, R., Rice, J., Abdoh, A., Mercer, D. and Bertrand, W. (1993) Maternal Behavioural Risk Factors for Severe Childhood Diarrhoeal Disease in Kinshasa. International Journal of Epidemiology, 22, 327333. http://dx.doi.org/10.1093/ije/22.2.327

[13] Gil, A., Lanata, C., Kleinau, E. and Penny, M. (2004) Children’s Feces Disposal Practices in Developing Countries and Interventions to Prevent Diarrheal Diseases. A Literature Review. Environmental Health Project. US Agency for International Development, Washington DC, 67 p.

[14] Judah, G., Donachie, P., Cobb, E., Schmidt, W., Holland, M. and Curtis, V. (2009) Dirty Hands: Bacteria of Faecal Origin on Commuter's Hands. Epidemiology and Infection, 138, 409-414. http://dx.doi.org/10.1017/S0950268809990641

[15] Gentilini, M. and Viens, P. (1993) Tropical Communicable Diseases. Eurotext, Paris, 132 p.

[16] Barreto, M.L., Miloroy, C.A., Strina, A., Prado, M.S., Leite, J.P., Ramos, E.A.G., et al. (2006) Community Based Monitoring of Diarrhoea in Urban Brazilian Children: Incidence and Associated Pathogens. Transactions of the Royal Society of Tropical Medicine and Hygiene, 100, 234-242. http://dx.doi.org/10.1016/j.trstmh.2005.03.010 
Scientific Research Publishing (SCIRP) is one of the largest Open Access journal publishers. It is currently publishing more than 200 open access, online, peer-reviewed journals covering a wide range of academic disciplines. SCIRP serves the worldwide academic communities and contributes to the progress and application of science with its publication.

Other selected journals from SCIRP are listed as below. Submit your manuscript to us via either submit@scirp.org or Online Submission Portal.
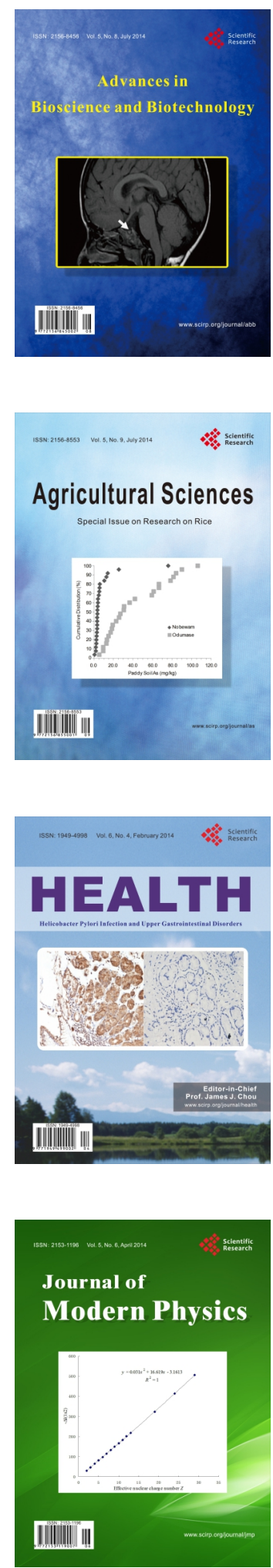
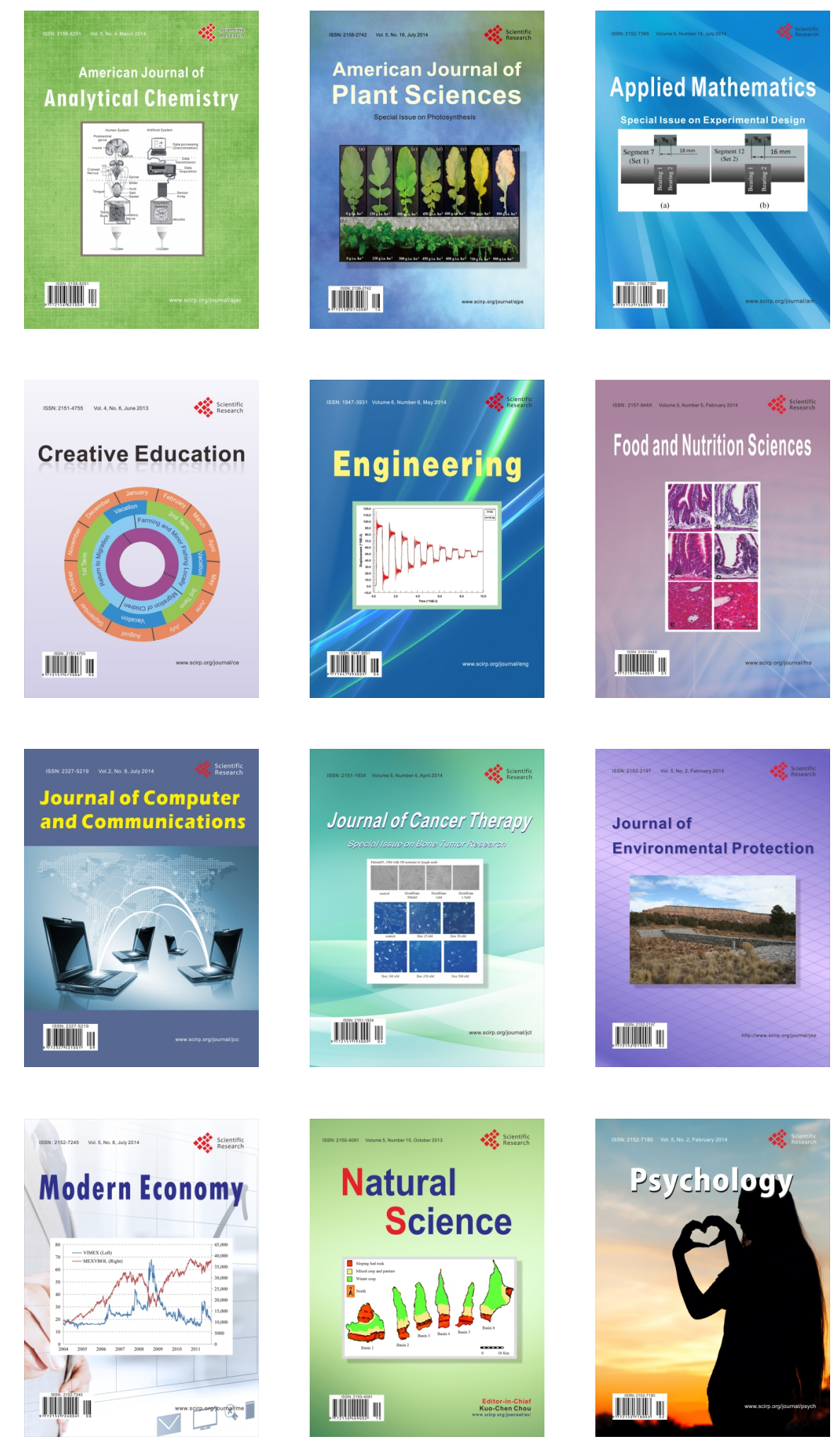